\title{
Peningkatan Nilai Perusahaan Melalui Struktur Modal Dan Corporate Social Responsibility Pada Perusahaan Food And Beverage Di Bei
}

\author{
Nuryati*), Hariyanti \\ STIE - Adi Unggul Bhirawa Surakarta \\ nuryatiharto@yahoo.co.id ${ }^{1)}$; hariyanti_da@yahoo.co.id ${ }^{2)}$ \\ 2019
}

\begin{abstract}
Abstraksi
Penelitian ini bertujuan untuk mengetahui apaakah dengan pengungkapan corporate social responsibility mampu memediasi hubungan struktur modal terhadap nilai perusahaan food \& bevearage yang terdaftar di Bursa Efek Indonesia (BEI) bagaimana meningkatkan nilai perusahaan yang di[proksi dengan Price Book Value melalui peningkatan struktur modal yang diproksi dengan Long Term Debt to Total Assests dan Debt to Equity Ratio dengan pengungkapan Corporate social Responsibility sebagai variabel mediasi. Hasil penelitian dengan uji analisis jalur menunjukkan bahwa Long Term Debt to Total Assests dan Debt to Equity Ratio tidak perbengaruh terhadap Corporate social Responsibility maupun Price Book Value. Corporate social Responsibility berpengaruh terhadap Price Book Value. Corporate social Responsibility tidak memediasi hubungan struktur modal terhadap Nilai perusahaan.

Kata kunci : Long Term Debt to Total Assests, Debt to Equity Ratio, Corporate social Responsibility dan Price Book Value'
\end{abstract}

\section{Latar Belakang}

Perusahaan dibentuk dengan tujuan jangka panjangyaitu untuk memaksimalkan nilai perusahaan dengan meningkatkan kemakmuran parapemilik atau pemegang saham. Nilai perusahaan adalah suatu keadaan tertentu yang telah diraih perusahaan dimana menggambarkan persepsi investor terhadap kinerja manajemen dalam mengelola perusahaan melalui serangkaian proses pelaksanaan fungsi manajemen dari semenjak perusahaan didirikan hingga saat ini. Nilai perusahaan yang tinggi menunjukkan prestasi kinerja yang baik sehingga menjadi keinginan parapemiliknya. Semakin tingginilai perusahaan, semakin besar kemakmuran yang akan diterima oleh pemilik perusahaan(Wiagustini, 2013:9)..

Nilai perusahaan adalah harga yang bersedia dibayar oleh calon pembeli apabila perusahaan tersebut dijual yang dikaitkan dengan harga saham (Kusumajaya, 2011). Semakin tinggi harga saham suatu perusahaan di pasar modal, maka menunjukkan semakin tingginya kekayaan pemilik perusahaan yang tercermin dari semakin tingginya nilai perusahaan. Menunjukkan bahwa kinerja perusahaan dalam keadaan baik sehingga dapat meyakinkan investor akan baiknya prospek perusahaan di masa mendatang.

Nilai perusahaan yang tinggi menggambarkan bahwa kinerja perusahaan dalam keadaan baik sehingga dapat meyakinkan investor akan baiknya prospek perusahaan di masa mendatang. Nilai perusahaan dapat diukur dengan menggunakan rasio keuangan, salah satunya price to book value (PBV). Rasio PBV merupakan perbandingan market value suatu saham terhadap book value, sehingga dapat diketahui apakah tingkat harga sahamnya overvalued atau undervalued dari book value. Nilai PBV yang rendah dicerminkan melalui harga saham yang undervalued dimana mengindikasikan adanya penurunan kualitas dan kinerja. fundamental emiten. Harga saham yang overvalued atau nilai PBV yang tinggi mencerminkan persepsi investor yang berlebihan terhadap perusahaan.

Dewasa ini masyarakat semalin cermat dalam menilai dampak sosial yang ditimbulkan perusahaan dari produknya, CSR yidak hanya sebatas peduli lingkungan saja, tetapi juga kepada seluruh pemangku kepentingan diantaranya karyawan, pelanggan, kreditur, pemegang saham dan komunitas. Manajemen harus memahami kepentingan sosial dan ekonomi (Parengkuan dkk, 2017). Program CSR adalah investasi bagi perusahaan demi pertumbuhan dan keberlanjutan (Sustainability) perusahaan. Bukan lagi sebagai sarana biaya, melainkan sebagai sarana meraih keuntungan. Program CSR merupakan komitmen perusahaan untuk melaksanakan akyivitas dan pengambilan keputusan, 
tidak hanya factor keuangan semata melainkan harus berdasarkan konsekwensi sosial dan lingkungan untuk saat ini dan masa mendatang. CSR merupakan isi pasal 74 Undang-Undang Persero Terbatas No.40 Tahun 2007. Undang- Undang tersebut mewajibkan perusahaan yang melakukan kegiatan usaha dibidang /terkait dengan PT. No 40.Tahun2007 dinyatakan bahwa semua perusahaan wajib untuk melaporkan pelaksanaan tanggungjawab sosial dan limgkungan.

Annual report merupakan sarana komunikasi perusahaan dengan pihak-pihak eksternal, telah dianjurkan dalam PSAK No.1 Tahun 2009 Paragraf 9 tentang penyajian laporann keuangan bertanggungjawab atas laporan dinyatakan bahwa: Perusahaan dapat pula menyajikan laporan keuangan dapat pula menyajikan laporan tambahan seperti laporan mengenai lingkungan hidup laporan nilai tambah ( value added statement), khususnya bagi industri dimana faktor-faktor lingkungan hidup memegang peranan penting.

CSR tidak lagi dihadapkan pada tanggungjawab yang berpijak pada single bottom line, yaitu nilai perusahaan (corporate value) yang direfleksikan dalam kondisi keuangannya (financial) saja. Tapi tanggungjawab perusahaan harus berpijak pada triple bottom lines. Disini bottom lines lainnya selain finansial juga ada sosial dan lingkungan, karena kondisi keuangan saja tidak cukup menjamin nilai perusahaan tumbuh secara berkelanjutan (sustainable). Keberlanjutan perusahaan hanya akan terjamin apabila perusahaan memperhatikan dimensi sosial dan lingkungan hidup. Sudah menjadi fakta bagaimana resistensi masyarakat sekitar, di berbagai tempat dan waktu muncul ke permukaan terhadap perusahaan yang dianggap tidak memperhatikan aspek-aspek sosial, ekonomi dan lingkungan hidupnya.

Menurut Darwin (Rakhiemah dan Agustia,2009) perusahaan dapat memperoleh banyak manfaat dari praktik dan pengungkapan CSR apabila dipraktekkan dengan sungguh-sungguh, diantaranya: dapat mempererat komunikasi dengan stake holders, meluruskan visi, misi, dan prinsip perusahaan terkait dengan praktik dan aktivitas bisnis internal perusahaan,mendorong perbaikan perusahaan secara berkesinambungan sebagai wujud manajemen risiko dan untuk melindungi reputasi,serta untuk meraih competitive advantage dalam hal modal, tenaga kerja, supplier, dan pangsa pasar.

Joel G. Siegel dan Jae K. Shim (1999) dalam Nuryati dan Hariyanti (2016) mengatakan Capital Structure (struktur modal) adalah komposisi saham biasa, saham preferen, laba yang ditahan, dan utang jangka panjang yang dipertahankan oleh kesatuan usaha dalam mendanai aktiva. Struktur modal merupakan gambaran dari bentuk proporsi finansial perusahaan yaitu antara modal yang dimiliki yang bersumber dari utang jangka panjang (long term liabilities) dan modal sendiri (shareholders' equity) yang menjadi sumber pembiayaan suatu perusahaan. Pendapat ini dipertegas oleh Jones (1992) bahwa struktur modal suatu perusahaan terdiri dari long - term debt dan Stockholder equity. Stockholder equity terdiri dari preferredstock dan commonstock.

Kebijaksanaan struktur modal pada dasarnya dibangun dari hubungan antara keputusan dalam pemilihan sumber dana (financing decision) dengan jenis investasi yang harus dipilih oleh perusahaan (invesment decisioni) agar sejalan dengan tujuan perusahaan. Tujuan perusahaan yaitu memaksimalkan kesejahteraan pemegang saham (maximize share of firm) atau nilai pasar dari harga saham (maximize share holders wealth) yang tercermin dari nilai perusahaan (valvue of firm) atau nilai pasar dari harga saham perusahaan. Proporsi antara penggunaan modal sendiri dan hutang dalam memenuhi kebutuhan dana perusahaan disebut dengan struktur modal perusahaan. Struktur modal yang optimal suatu perusahaan harus berada pada keseimbangan antara resiko dan pengembalian yang memaksimumkan harga saham. (Brigham dan Houston, 2001).

Struktur modal adalah bertujuan untuk memadukan sumber dana permanen yang selanjutnya digunakan perusahaan dengan cara yang diharapkan akan mampu memaksimumkan nilai perusahaan. Bagi sebuah perusahaan sangat penting untuk memperkuat kestabilan keuangan yang dimilikinya, karena perubahan dalam struktur modal bisa menyebabkan perubahan nilai perusahaan. (Fahmi, 2011 : 185).

Penelitian ini hanya meneliti perusahaan Food and Beverage yang terdaftar di Bursa Efek Indonesia (BEI) dari tahun 2012 sampai dengan tahun 2016. Variabel yang diteliti berupa struktur modal diproksi dengan Long Term Debt to Total Assest (LTDA) dan Debt Equity Ratio (DER) dan nilai perusahaan diproksi dengan Price Book Value (PBV). Peneliti ingin mengetahui apakah CSR mampu memediasi struktur modal terhadap nilai perusahaan 


\section{A. TINJAUAN PUSTAKA}

\section{Nilai Perusahaan}

Nilai perusahaan merupakan konsep penting bagi investor karena menjadi indikator bagi pasar untuk menilai perusahaan secara keseluruhan.Nilai perusahaan juga dapat diartikan sebagai penilaian yang dilakukan investor terhadap tingkat keberhasilan perusahaan dalam mengelola sumber daya yang dimilikinya. Nilai perusahaan dapat meningkat jika institusi mampu menjadi alat monitoring yang efektif (Gunawan dan Utami, 2008).

Menurut Darminto (2010), nilai perusahaan menunjukkan nilai dari berbagai aset yang dimiliki oleh perusahaan termasuk surat berharga yang dikeluarkannya dan untuk perusahaan go public, nilai perusahaan dapat tercermin melalui harga sahamnya. Harga saham dari perusahaan harus dapat dibuat seoptimal mungkin,apabila harga saham terlalu tinggi, maka perusahaan akan takut jika investor tidak akan membeli, namun apabila harga saham terlalu rendah dapat berdampak buruk pada citra perusahaan (Wardani danHermuningsih, 2011).

Nilai perusahaan sangat penting artinya bagi suatu perusahaan karena semakin tinggi nilai perusahaan, maka semakin tinggi kemakmuran pemegang saham. Menurut Retno dan Priantinah (2012), para pemodal menyerahkan pengelolaan perusahaan kepada para profesional,yaitu manajer ataupun komisaris agar pencapaian nilai perusahaan dapat meningkat. Nilai perusahaan yang meningkatakan memberikan sumbangan pertumbuhan jangka panjang bagi perusahaan (Sukasih dan Susilawati, 2011). Menurut Kusumajaya (2011), terdapat variabel-variabel kuantitatif yang digunakan untuk memperkirakan nilai perusahaan,yaitu: (1) Nilai buku merupakan total ekuitas pemegang saham dibagi dengan jumlah saham yang beredar; 2) Nilai pasar merupakan suatu pendekatan untuk memperkirakan nilai bersih dari perusahaan. Apabila saham dari perusahaan diperdagangkan dalam bursa sekuritas, maka nilai perusahaan dapat diukur berdasarkan nilai pasarnya; (3) Nilai apprasial, diperoleh dari perusahaan independent appraiser; (4) Nilai arus kas, digunakan ketika melakukan penilaian mergeratau akuisisi untuk mengestimasi arus kas bersih.

\section{Corporate Social Responsibility (CSR)}

\section{Teori Stakeholder}

Konsep tanggungjawab sosial perusahaan telah mulai dikenal sejak awal 1970-an,yang secara umum dikenal dengan stakeholdertheory artiny sebagai kumpulan kebijakan dan praktik yang berhubungan dengan stakeholder, nilai-nilai, pemenuhan ketentuan hukum, penghargaan masyarakat dan lingkungan, serta komitmen dunia usaha untuk berkontribusi dalam pembangunan secara berkelanjutan. Stakeholder theory dimulai dengan asumsi bahwa nilai (value) secara eksplisit dan tak dipungkiri merupakanbagian dari kegiatan usaha. (Freeman, et all., 2002 dalam Oktavia \& Hermi, 2014).

Teori stakeholder mengatakan bahwa perusahaan bukanlah entitas yang hanya beroperasi untuk kepentingan sendiri namun harus memberikan manfaat bagi stakeholdernya.Dengan demikian, keberadaan suatu perusahaan sangat dipengaruhi oleh dukungan yang diberikan oleh stakeholder kepada perusahaan tersebut (Ghozali dan Chariri, 2007). Stakeholder pada dasarnya dapat mengendalikan atau memiliki kemampuan untuk mempengaruhi pemakaian sumber-sumber ekonomi yang digunakan perusahaan. Oleh karena itu power stakeholder ditentukan oleh besar kecilnya power yang dimiliki stakeholder atas sumber tersebut (Ghozali dan Chariri,2007). Power tersebut dapat berupa kemampuan untuk membatasi pemakaian sumber ekonomi yang terbata (modal dan tenagakerja), akses terhadap media yang berpengaruh, kemampuan untuk mengatur perusahaan,atau kemampuan untuk mempengaruhi konsumsi atas barang dan jasa yang dihasilkan perusahaan (Ghozali dan Chariri,2007). Oleh karena itu,"ketika stake holder mengendalikan sumber ekonomi yang penting bagi perusahaan, maka perusahaan akan bereaksi dengan berbagai cara yang memuaskan keingina nstakeholder"'(GhozalidanChariri,2007).

Atas dasar argumen diatas,teori stakeholder umumnya berkaitan dengan cara-cara yang digunakan perusahaan untuk memanage stakeholdernya. Cara-cara yang dilakukan untuk memanage stakeholdernya tergatung strategi yang dapat mengadopsi oleh perusahaan. strategi aktif atau pasif. Strategi aktif adalah apabila perusahaan berusaha mempengaruhi hubungan organisasinya dengan stakeholder yang dipandang berpengaruh penting. Sedangkan perusahaan yang mengadopsi strategi pasif cenderung tidak terus menerus memonitor aktivitas stakeholder dan secara sengaja tidak 
mencari strategi optimal untuk menarik perhatian stakeholder. Akibat dari kurangnya perhatian terhadap stakeholder adalah rendahnya tingkat pengungkapan informasi sosial dan rendahnya kinerja sosial perusahaan. (Ghozalidan Chariri, 2007).

\section{Pertanggungjawaban Sosial Perusahaan}

Menurut The World Business Council for Sustainable Development (WBCSD), Corporate Social Responsibility atau tanggung jawab sosial perusahaan didefinisikan sebagai komitmen bisnis untuk memberikan kontribusi bagi pembangunan ekonomi berkelanjutan, melalui kerja sama dengan para karyawan serta perwakilan mereka, keluarga mereka, komunita ssetempat maupun masyarakat umum untuk meningkatkan kualitas kehidupan dengan cara yang bermanfaat baik bagi bisnis sendiri maupun untuk pembangunan. Pertanggungjawaban sosial perusahaan ini diungkapkan didalam laporan yang disebut dengan Sustainability Reporting. Sustainability Reporting adalah pelaporan mengenai kebijakan ekonomi, lingkungan dan sosial, pengaruh dan kinerja organisasi dan produknya didalam konteks pembangunan berkelanjutan (sustainable development). Sustainability Reporting meliputi pelaporan mengenai ekonomi, lingkungan dan pengaruh sosial terhadap kinerja organisasi (Anggraini,2006). Sustainability report harus menjadi dokumens trategik yang berlevel tinggi yang menempatkan isu, tantangan dan peluang Sustainability Development yang membawanya menuju kepada corebusiness dan sektor industrinya. Berkaitan dengan pelaksanaan CSR, perusahaan bisa dikelompokkan kedalam beberapa kategori.Meskipun cenderung menyederhanakan realitas, tipologi ini menggambarkan kemampuan dan komitmen perusahaan dalam menjalankan CSR. Pengkategorian dapat memotivasi perusahaan dalam mengembangkan program CSR,dan dapat pula dijadikan cermin dan guideline untuk menentukan model CSR yang tepat (Suharto, 2007). Dengan menggunakan dua pendekatan, sedikitnya ada delapan kategori perusahaan. Perusahaan ideal memiliki kategori reformis dan progresif. Tentu saja dalam kenyataannya, kategori ini bisa saja saling bertautan. Pertama. Berdasarkan proporsi keuntungan perusahaan dan besarnya anggaran CSR: (1)Perusahaan Minimalis; (2) Perusahaan Ekonomis; (3)Perusahaan Humanis; (4)Perusahaan Reformis. Kedua. Berdasarkan tujuan CSR: apakah untuk promosi maupunpemberdayaan masyarakat:(1) Perusahaan Pasif; 2)Perusahaan Impresif; (3)Perusahaan Agresif; (4)PerusahaanProgresif.

\section{PengungkapanTanggung JawabSosial Perusahaan}

Pengungkapan tanggungjawab sosial merupakan data yang diungkap oleh perusahaan berkaitan dengan aktifitas sosialnya yang meliputi indikator kinerja ekonomi, lingkungan dan sosial. Indikator kinerja sosial mencakup empat indikator yang terdiri dari: indikator kinerja tenaga kerja, hak asasi manusia, sosial/kemasyarakatan, dan produk. Karena indikator ini lebih memfokuskan pada pertanggungjawaban perusahaan, sehingga para investor dapat menjadikan informasi tersebut sebagai bahan pertimbangan dalam berinvestasi. (Siregar, 2008). Perhitungan variabel ini dilakukan oleh peneliti dengan mengukur pengungkapan tanggungjawab sosial laporan tahunan yang dilakukan dengan pengamatan mengenai ada tidaknya suatu item informasi yang ditentukan dalam laporan tahunan dengan asumsi setiap yang diungkapkan pasti telah dilakukan, apabila item informasi tidak ada dalam laporan keuangan maka diberi skor 0, dan jika item informasi yang ditentukan ada dalam laporan tahunan maka diberi skor 1. Metode pengukuran ini dinamakan dengan Checklist data.

\section{Struktur Modal}

\section{Pengertian}

Modal (pembelanjaan dari luar perusahaan) dikelompokkan dalam dua jenis, yakni: hutang dan ekuitas. Menurut Brigham dan Gapenski (1997: 767-768), hutang mempunyai keunggulan berupa : 1) bunga mengurangi pajak sehingga biaya hutang rendah, 2) kreditur memperoleh keuntungan terbatas sehingga pemegang saham tidak perlu berbagi keuntungan ketika kondisi bisnis sedang maju, 3) kreditur tidak memiliki hak suara sehingga pemegang saham dapat mengendalikan perusahaan dengan penyertaan dana yang kecil. Meskipun demikian, hutang juga mempunyai kelemahan, yaitu: 1) hutang biasanya berjangka waktu tertentu untuk dilunasi tepat waktu, 2) rasio hutang yang tinggi akan meningkatkan risiko yang selanjutnya akan meningkatkan biaya modal, 3) bila perusahaan 
$\overline{\text { dalam kondisi sulit dan labanya tidak dapat memenuhi beban bunga maka tidak tertutup kemungkinan }}$ dilakukan tindakan likuidasi.

\section{Teori-teori Struktur Modal}

Kecenderungan perusahaan yang makin banyak menggunakan hutang, tanpa disadari secara berangsur-angsur, akan menimbulkan kewajiban yang makin berat bagi perusahaan saat harus melunasi (membayar kembali) hutang tersebut.Tidak jarang perusahaan- perusahaan yang akhirnya tidak mampu memenuhi kewajiban tersebut, dan bahkan dinyatakan pailit.Hingga kini belim ada rumusan matematik yang tepat untuk menentukan jumlah optimal dari hutang dan ekuitas dalam struktur modal (Seits,1984: 301).Pedoman umum hanyalah; mencari hutang sebanyak mungkintanpa meningkatkan resiko atau menurunkan fleksibilitas perusahaan.

Franco Modigliani dan Merton Miller adalah bapak dari teori struktur modal (Groth and Anderson, 1997). Pada tahun 1958, dalamAmerican Economic Review 48 (1958. June) yang berjudul The Cost of Capital. Cotporate Finance, and the Theory of Investment, mereka mengemukakan teori struktur modal dengan berbagai asumsi yang tidak mungkin terjadi, akan tetapi sangat membantu dalam memahami bagaimana perusahaan menentukan bauran pendanaan yang berasal dari hutang dan ekuitas secara benar (Siaw, 1999). Asumsi-asumsi yang mendasari adalah (Megginson, 1997: 316):

a. Semua aktiva berujud dimiliki oleh perusahaan

b. Pasar modal sempurna (tidak ada pajak, tidak ada biaya transaksi, dan tidak ada biaya kebangkrutan).

c. Perusahaan hanya dapat menerbitkan dua macam sekuritas, yakni ekuitas yang berisiko dan hutang bebas (tanpa) risiko.

d. Individu maupun perusahaan dapat meminjam atau meminjamkan uang dengan tingkat suku bunga bebas risiko.

e. Para investor mempunyai ekspektasi yang lama (homogen) terhadap keuntungan perusahaan di masa mendatang.

f. Semua perusahaan tidak mengalami pertumbuhan (arus kas diasumsikan konstan dan perpetual, dan semua laba dibagikan dalam bentuk dividen).

g. Semua perusahaan dapat dikelompokkan dalam seta kelompok kembalian, dan kembalian saham dari semua perusahaan dalam keiompok tersebut adalah proporsional.

Hubungan pertumbuhan perusahaan dengan kebijaksanaan struktur modal telah banyak diteliti oleh peneliti sebelumnya. Smitts dan Watts (1992) menyatakan bahwa potensi pertumbuhan suatu perusahaan akan mempengaruhi kebijakan yang dibuat oleh perusahaan (seperti kebijakan pendanaan, deviden, dan kompensasi). Smitts dan Watts menemukan adanya bukti bahwa pada perusahaan yang berpotensi untuk tumbuh mempunyai rasio debt to equity yang lebih rendah dari pada perusahaan yang tidak tumbuh. Kecenderungan ini dilakukan untuk mengurangi masalah agensi yang potensial berasosiasi dengan eksistensi hutang yang berisiko dalam struktur modalnya.

Indonesiaa sebagai negara yang sedang berkembang sering menggantikan hutang jangka pendek menjadi hutang jangka panjang dan roll over hutang jangka pendek (Husnan, 2001; Pandey, 2002). Pengukuran dari variabel struktur modal didefinisikan sebagai komposisi modal perusahaan dilihat dari sumbernya khususnya yang menunjukkan porsi dari modal perusahaan yang berasal dari sumber hutang (kreditur) dan sekaligus porsi modal yang berasal dari pemilik sendiri (owner's equity). Variabel struktur modal diukur dengan menggunakan tiga indikator, yaitu laverage, debt to equity, dan collaterallizable assets. Leverage mencerminkan penggunaan sumber dana yang berasal dari hutang jangka panjang (modal asing) yang menimbulkan beban tetap bagi perusahaan, seperti beban bunga. Nilai dari indikator ini ditentukan menggunakan longterm debt to total assets, debtto equity, dan collaterallizable assets (Sugeng, 2009: 42). Dalam penelitian ini struktur modal diukur dengan long-term debt to total assets dan debt to equity. Collaterallizable assets tidak digunakan karena tidak berpengaruh terhadap nilai perusahaan.

Struktur modal dapat dianalisis dengan melihat pada tanda-tanda dan atribut yang mengkarakteristik aset-aset perusahaan dan yang berpengaruh dengan level intensitas yang berbeda, kegiatan 
pengelolaan perusahaan. Oleh karena itu, ekuitas dan hutang harus dipertimbangkan baik sebagai instrumen-instrumen keuangan maupun corporate governance. Menurut Williamson SM (1988), hutang memerlukan kegiatan pengelolaan manajemen yang ketat, sementara ekuitas memungkinkan fleksibilitas yang lebih besar terhadap kekuasaan dan pengambilan keputusan..

\section{Pengaruh Struktur Modal terhadap Corporate Social Responsibility (CSR)}

Adanya paradigm baru dimana nilai perusahaan tidak lagidipengaruhi oleh sektor fundamental, salah satunya adalah struktur modal.Seiring pergeseran waktu tekanan pengungkapan corporate social responsibility (CSR) memberikan dampak pada nilai perusahaan.Beberapa tahun terakhir banyak perusahaan semakin menyadari pentingnya pengungkapan CSR sebagi bagian dari strategi bisnis. Salah satu manajemen melakukan pelaporan sosial adalah untuk alasan strategis (Kusuma dan Oka, 2017).

Struktur modal telah menjadi salah satu faktor pertimbangan investasi yang cukup penting. Hal ini berkaitan dengan resiko dan pendapatan yang akan dijadikan bahan pertimbangan bagi investor untuk menanamkan modalnya. Para investor akan melakukan berbagai analisis terkait dengan keputusan untuk menanamkan modalnya pada perusahaan melalui informasi yang salah satunya berasal dari laporan keuangan perusahaan. Teori struktur modal menjelaskan kebijakan pendanaan perusahaan yang berkenaan dengan hutang dan equitas digunakan untuk memaksimalkan nilai perusahaan (Husnan. S dan E. Pudjiastuti, 2004 : 91).

Berdasarkan hasil penemuan empiris danteori diatas dapat dirumuskan hipotesis sebagai berikut:

$\mathrm{H}_{1}$ : Long Term Debt to Total Assets (LTDA) berpengaruh signifikan terhadap Corporate Social Responsibility (CSR)

$\mathrm{H}_{2}$ : Debt to Equity Ratio (DER) berpengaruh signifikan terhadap Corporate Social Responsibility (CSR).

\section{Pengaruh Sruktur Modal yang terhadap Nilai Perusahaan}

Nilai perusahaan (firm value) merupakan konsep yang penting bagi investor, karena merupakan indikator yang penting bagaimana pasar menilai perusahaan secara keseluruhan. Nilai pasar publik ditentukan oleh harga pasar saham (Walsh, 2004: 144). Harga pasar saham mencerminkan potensi perusahaan di masa datang atau penilaian investor secara keseluruhan atas ekuitas yang dimiliki suatu perusahaan tertentu. .

Menurut pecking order theory, dana eksternal lebih disukai dalam bentuk hutang daripada modal sendiri karena pertimbangan biaya emisi. Manajer dapat menggunakan hutang sebagai sinyal yang lebih terpercaya untuk para investor. Ini karena perusahaan yang meningkatkan hutang dapat dipandang sebagai perusahaan yang yakin dengan prospek perusahaan di masa yang akan datang dan hal ini bisa meningkatkan nilai perusahaan di mata investor. (Ragil \& Sri Ayem, 2016).

Dewi dan Wirajaya (2013) melakukan penelitian tentang pengaruh struktur modal terhadap nilai perusahaan dengan hasil struktur modal berpengaruh signif ikan negatif terhadap nilai perusahaan. Penelitian ini di dukung oleh penelitian yang dilakukan oleh Ragil dan Sri Ayem (2016). Berbeda dengan penelitian yang dilakukan oleh Gayatri dan Mustanda (2014) yang menyatakan bahwa struktur modal berpengaruh signifikan positif terhadap nilai perusahaan.

Komposisi hutang terhadap ekuitas dalam hal ini Debt to Equity Ratio digunakan sebagai indikator penting yang menggambarkan kemampuan ekuitas pemegang saham perusahaan, atau dengan kata lain kemampuan modal emiten dalam membayar hutangnya.Bila makin besar rasio ini, berdasarkan teri struktur modal berarti semakin besar nilai perusahaan, karena biaya bunga hutang adalah biaya yang mengurangi pajak. Namun setelah titik optimal penambahan hutang berarti risiko yang akan ditanggung perusahaan juga semakin besar (Widjaja,2009: 26).

Variabel struktur modal diukur menggunakan tiga indikator, yaitu leverage debt to equity, dan collaterallizable assets (Sugeng,2009:42). Leverage mencerminkan penggunaan sumber dana yang berasal dari hutang jangka panjang (modal asing) yang menimbulkan beban tetap bagi perusahaan, seperti beban bunga. Dalam penelitian ini struktur modal diukur dengan long-term debt to total assets dan debt to equity ratio. Collaterallizable assets tidak digunakan karena tidak berpengaruh terhadap nilai perusahaan.

Dari pembahasan di atas dapat dirumuskan hipotesis sebagai berikut :

$\mathrm{H}_{3}$ : Long Term Debt to Total Assets (LTDA) berpengaruh signifikan terhadap Nilai Perusahaan 
$\mathrm{H}_{4}$ : Debt to Equity Ratio (DER) berpengaruh signifikan terhadap nilai perusahaan

\section{Pengaruh Corporate Social Responsibility (CSR) terhadap Nilai Perusahaan}

Pengungkapan CSR yang lebih luas akan berdampak positifterhadap nilai perusahaan (Jo dan Harjoto, 2011). Pengungkapan CSR yang lebih luas akan membuat perusahaan memperoleh dukungan atas keberpihakan stakeholder terhadap segala keputusan yang diambil dalam rangka meningkatkan nilai perusahaan. Hasil penelitian yang dilakukan oleh Servaes dan Tamayo (2013), Harjoto dan Jo (2011), Fodioet al. (2013),Gherginaet al. (2014), Nguyenetal.(2015) dan Silvia (2012) juga menemukan bahwa CSR berpengaruh positif dan signifikan terhadap nilai perusahaan. Berdasarkan teori dan penelitian tersebut, maka dapat diajukan hipotesis sebagai berikut:

$\mathrm{H}_{5}$ :Corporate Social Responsibility (CSR) berpengaruh signifikan terhadap Nilai Perusahaan (PBV).

\section{Kerangka Pemikiran Teoritis}

Model Penelitian yang dibangun melakukan pengujianstruktur modal yang diproksi dengan long term debt to assets (LTDA) dan debt to equity ratio (DER), corporate socialresponsibility (CSR), dan nilai perusahaan yang diproksi dengan PBV. Permasalahan utama yang dikaji dalam penelitian ini adalah pentingnya kajian struktur modal denganpengungkapan corporate socialresponsibility (CSR) untuk meningkatkan nilai perusahaan.Berdasarkan model teori dasar dan pengembangan hipotesis maka dicoba dikembangkan model penelitian empiris, yang terlihat pada gambar 1.berikut ini

STRUKTUR MODAL

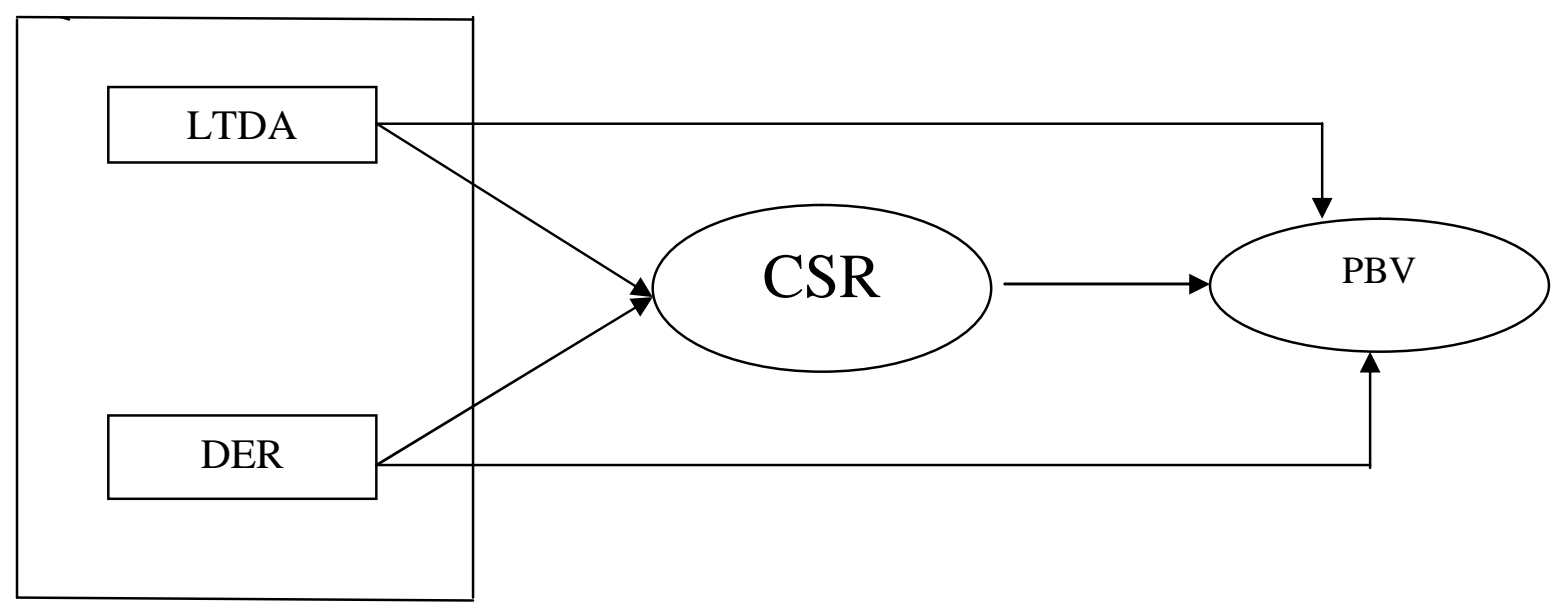

Gambar 3. Model Penelitian struktur modal (LTDA) dan DER) terhadap CSR bisnis dan nilai perusahaan (PBV).

\section{METODE PENELITIAN}

\section{Populasi dan sampel}

Penelitian ini menggunakan data sekunder yaitu laporan tahunan perusahaan food \& beverage yang terdaftar di Bursa Efek Indonesia (BEI) dengan cara mengakses situs resmi BEI yang terdaftar di Indonesian Capital Market Directory ( ICMD ) dan yang menerbitkan laporan tahunan secara berturut-turut selama tahun 2012-2016, merupakan populasi yang diteliti dalam penelitian ini.

\section{Definisi Operasional Variabel Penelitian Variabel Nilai Perusahan}

Variabel dependen ( $\left.\mathrm{Y}_{2}\right)$ dalam penelitian ini adalah nilai perusahaan. Nilai perusahaan merupakan harga yang bersedia dibayar oleh calon pembeli, yang diartikan sebagai harga pasar dari perusahaan itu sendiri (Ayuningtias, 2013). Dalam penelitian ini, nilai perusahaan dihitung menggunakan PBV (Price to Book Value), dimana rumus perhitungannya adalah sebagai berikut. 


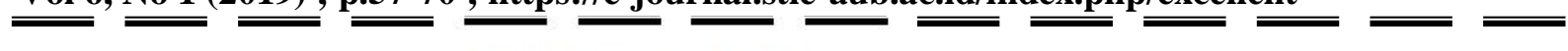 \\ Variabel struktur modal}

Pengukuran struktur modal menggunakan dua proksi, yaitu long term debt to total assets dan debt to equity rasio, Penggunaan Struktur modal ini diambil dari penelitian Sugeng (2009). N dari indikator ini ditentukan menggunakan long term debt to total assets (Jain, et al.,2003). Makin besar rasio ini makin tinggi sumber modal yang berasal dari hutang serta semakin kecil yang berasal dari modal sendiri/pemilik dan sebaliknya. long term debt to total assets ini diukur dengan rumus sebagai berikut:

$$
\text { Long term debt to total assets }=\frac{\text { Long term debt }}{\text { Total assets }}
$$

Long term debt to total assets merupakan variabel independen $\left(\mathrm{X}_{1}\right)=$ LTDTADebt to Equity ratio merupakan rasio antara total hutang (total debt) terhadap total ekuitas pemilik (owner's equity) dan mencerminkan porsi modal yang berasal dari hutang terhadap modal sendiri. Semakin tinggi rasio ini juga menunjukkan makin besar porsi modal yang dibiayai dari sumber hutang/modal asing, dan sebaliknya. Selain itu makin besar rasioini, berarti risiko yang akan ditanggung perusahaan juga semakin besar dan ini akan menentukan prospek perusahaan dimasa depan (Widjaja,2009: 26). Debt to equity ratio diukur dengan rumus:

$$
\begin{aligned}
& \text { Debt to equity }=\frac{\text { Total Debt }}{\text { Owner's equity }} \\
& \text { Debt to equity merupakan variabel independen }\left(\mathrm{X}_{2}\right)=\text { DTA }
\end{aligned}
$$

\section{Variabel Corporate social responsibility ( CSR)}

Pengungkapan tanggungjawab sosial merupakan data yang diungkap oleh perusahaan berkaitan dengan aktifitas sosialnya yang meliputi indikator kinerja ekonomi, lingkungan dan sosial. Indikator kinerja sosial mencakup empat indikator yang terdiri dari: indikator kinerja tenaga kerja, hak asasi manusia, sosial/kemasyarakatan, dan produk. Karena indikator ini lebih memfokuskan pada pertanggungjawaban perusahaan, sehingga para investor dapat menjadikan informasi tersebut sebagai bahan pertimbangan dalam berinvestasi. (Siregar, 2008). Perhitungan variabel ini dilakukan oleh peneliti dengan mengukur pengungkapan tanggungjawab sosial laporan tahunan yang dilakukan dengan pengamatan mengenai ada tidaknya suatu item informasi yang ditentukan dalam laporan tahunan dengan asumsi setiap yang diungkapkan pasti telah dilakukan, apabila item informasi tidak ada dalam laporan keuangan maka diberi skor 0 , dan jika item informasi yang ditentukan ada dalam laporan tahunan maka diberi skor 1. Metode pengukuran ini dinamakan dengan Checklist data.

\section{ANALISA DATA DAN PEMBAHASAN}

Dalam bab ini akan disajikan analisis terhadap data penelitian dan pengujian hipotesis yang telah dikemukakan pada bab sebelumnya dengan menggunakan tehnik-tehnik analisis yang telah ditentukan. Sesuai dengan perumusan masalah dan tujuan penelitian yang telah dikemukakan bahwa tujuan dari penelitian ini adalah untuk memperoleh bukti empiris pengaruh struktur modal yang diukur dengan long term debt to total assets dan debt to equity ratio terhadap nilai perusahaan yang diukur dengan PBV, dengan corporate social responcibility sebagai variabel intervening perusahaanperusahaan yang terdaftar di BEI. Pengujian hipotesis menggunakan uji Analisis Jalur. 


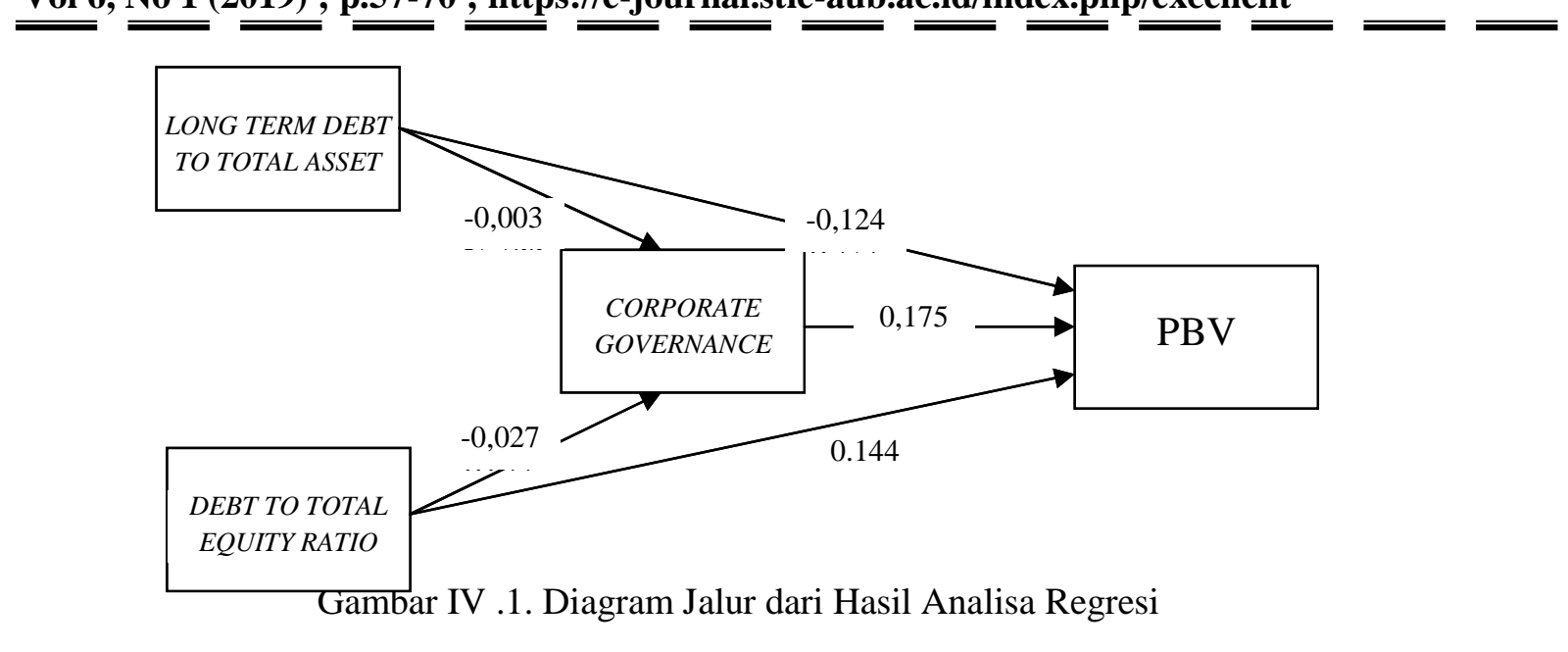

Tujuan analisis jalur adalah memperhitungkan pengaruh langsung dan tidak langsung.Berdasarkan hasil analisis di atas dapat disusun kesimpulan analisis secara menyeluruh pada tabel berikut :

Tabel IV. 9. Hasil Regresi Jalur

\begin{tabular}{|c|c|c|c|c|c|c|}
\hline \multirow{2}{*}{ No } & \multirow{2}{*}{ Arah Hubungan } & \multicolumn{2}{|c|}{ Regresi } & \multicolumn{2}{|c|}{ Korelasi } & \multirow{2}{*}{$€_{i}$} \\
\hline & & Beta & Sig & $\mathrm{r}$ & Sig & \\
\hline 1. & LTDTA ke CSR & $-0,003$ & 0.979 & $-0,004$ & 0,969 & 0,999 \\
\hline 2. & DER ke CSR & $-0,027$ & 0.796 & $-0,027$ & 0,794 & \\
\hline 3. & LTDTA ke PBV & $-0,124$ & 0.226 & $-0,117$ & 0,258 & 0,935 \\
\hline 4. & DER ke PBV & 0,144 & 0.160 & 0,133 & 0,200 & \\
\hline 5. & CSR ke PBV & 0,175 & 0.089 & 0,171 & 0,097 & \\
\hline
\end{tabular}

Sumber : Data sekunder diolah, 2018

\section{INTERPRETASI DAN PEMBAHASAN HASIL PENELITIAN}

1. Pengaruh Struktur Modal yang diukur dengan Long Total Term Debt to Assets terhadap Nilai Perusahaan yang diukur dengan Price Book Value.

Hasil penelitian ini tidak mendukung penelitian yang dilakukan oleh Mas'ud (2008), dan Sujoko dan Soebiantoro (2007), namun mendukung penelitian yang dilakukan sebelumnya oleh Asnawi danWijaya (2006) .

Hasil uji secara bersama-sama dengan variabel lain juga tidak berpengaruh signifikan. Penelitian ini tidak mendukung penelitian yang dilakukan oleh Litov( 2005). Argumentasi yang dinyatakan oleh Daniri (2005) dua dari lima manfaat penerapan corporate social responsibility governance adalah (1) Memberikan kerangka acuan yang memungkinkan pengawasan perusahaan berjalan efektif. (2) Mengurangi biaya modal (cost of capital), yaitu sebagai dampak dari pengelolaan perusahaan yang baik. Namun dalam argumentasi tersebut tidak sependapat dengan hasil penelitian ini.

Penelitian ini tidak mendukung penelitian yang dilakukan sebelumnya oleh Klapper dan Love (2002), Black dkk (2005), serta Siddarta dan Cynthia (2005). Namun penelitian ini mendukung peneliti sebelumnya yang dilakukan oleh Darmawati dkk (2005). Dalam konteks ini sebagian besar dibuktikan secara empiris bahwa praktek coporate social responsibility yang baik berpengaruh terhadap nilai perusahaan. Perusahaan yang mempraktekkan Corporate social responsibilit dengan baik akan mampu menjelaskan dan menafsirkan kemampuan perusahaan untuk menciptakan nilai perusahaan (Zingals, 2000; Bhagat dan Jefferis,2002). Perusahaan yang memiliki nilai yang baik,maka investor akan mengeluarkan pengorbanan yang lebih untuk memiliki perusahaan (Sukamulya,2004).Hasil penelitian menunjukkan jalur struktur modal yang diukur dengan long term debt to total assets menuju nilai perusahaan yang diukur dengan price book value lebih efektif secara langsung, tanpa melalui corporate social responsibility. 
2. Pengaruh Struktur Modal yang diukur dengan Debt to Equity Ratio terhadap Nilai Perusahaan yang diukur dengan price book value.

Dari uji analisis jalur ( Diagram Path) menunjukan bahwa struktur modal yang diukur dengan debt to equity ratio berpengaruh langsung sebesar 0,144 terhadap nilai perusahaan yang diukur dengan price book value. Adapun struktur modal yang diukur dengan debt to equity ratio berpengaruh tidak langsung sebesar -0.032 terhadap nilai perusahaan yang diukur dengan price book value melalui corporate social responsibility sebagai variabel intervening. Hasil penelitian menunjukkan jalur struktur modal yang diukur dengan debt to equity ratio menuju nilai perusahaan yang diukur dengan price book value lebih efektif secara langsung, tanpa melalui corporate social responsibility.

- Hasil penelitian ini mendukung penelitian yang dilakukan oleh Smith dan Watts (1992), dan oleh Asnawi danWijaya (2006). Namun hasil penelitian ini tidak mendukung penelitian sebelumnya yang dilakukan oleh Widjaja (2009), yaitu berpengaruh dan berdampak positif.Argumentasinya adalah dalam kondisi semakin tinggi debt to equity ratio, semakin rendah nilai perusahaan. Dari rasio ini pemodal dapat melihat apakah perusahaan dalam keadaan mampu atau tidak dalam membayar hutang, sehingga semakin tinggi debt to equity ratio, semakin rendah nilai perusahaan, karena risiko perusahaan itu semakin besar karena perusahaan memiliki kewajiban untuk membayar beban tetap atas hutang.

Hasil penelitian ini tidak mendukung penelitian yang dilakukan oleh Litov( 2005). Argumentasi yang dinyatakan oleh Daniri (2005) dua dari lima manfaat penerapan corporate social responsibility governance adalah (1) Memberikan kerangka acuan yang memungkinkan pengawasan perusahaan berjalan efektif. (2) Mengurangi biaya modal (cost of capital), yaitu sebagai dampak dari pengelolaan perusahaan yang baik. Namun dalam argumentasi tersebut tidak sependapat dengan hasil penelitian ini.

Penelitian ini tidak mendukung penelitian yang dilakukan sebelumnya oleh Klapper dan Love (2002), Black dkk (2005), serta Siddarta dan Cynthia (2005),. Namun penelitian ini mendukung peneliti sebelumnya yang dilakukan oleh Darmawati dkk (2005). Dalam konteks ini sebagian besar dibuktikan secara empiris bahwa praktek coporate social responsibility governance yang baik berpengaruh terhadap nilai perusahaan. Perusahaan yang mempraktekkan Corporate social responsibility governance dengan baik akan mampu menjelaskan dan menafsirkan kemampuan perusahaan untuk menciptakan nilai perusahaan (Zingals, 2000; Bhagat dan Jefferis,2002). Perusahaan yang memiliki nilai yang baik,maka investor akan mengeluarkan pengorbanan yang lebih untuk memiliki perusahaan (Sukamulya,2004). Hasil penelitian menunjukkan jalur struktur modal yang diukur dengan debt to equity ratio menuju nilai perusahaan yang diukur dengan price book value lebih efektif secara langsung, tanpa melalui corporate social responsibility.

\section{KESIMPULAN}

Berdasarkan hasil analisis data dan pengujian hipotesis yang telah dilakukan maka dapat ditarik kesimpulan sebagai berikut :

1. Corporate social responsibility berpengaruh positif signifikan terhadap nilai perusahaan yang diukur dengan price book value pada perusahaan- perusahaan food \& beverage yang terdaftar di BEI.

2. Struktur modal yang diukur dengan long term debt to total assets dan debt to equity ratio, dan corporate social responsibility secara bersama-sama tidak berpengaruh terhadap nilai perusahaan yang diukur dengan price book value pada perusahaan- perusahaan food \& beverage yang terdaftar di BEI.

3. Hasil analisis jalur menunjukkan bahwa ;

a. Pengaruh langsung struktur modal yang diukur dengan long term debt total assets dan terhadap nilai perusahaan yang diukur dengan price book value lebih besar dari pengaruh tidak langsung struktur modal terhadap nilai perusahaan melalui mediasi corporate social responsibility, sehingga untuk meningkatkan nilai perusahaan dipilih jalur langsung. 
b. Pengaruh langsung struktur modal yang diukur dengan debt to equity ratio terhadap nilai perusahaan yang diukur dengan price book value dengan mediasi corporate social responsibility, sehingga untuk meningkatkan nilai perusahaan dipilih jalur langsung.

c. Pengaruh total strukur modal yang diukur dengan debt to equity ratio terhadap nilai perusahaan yang diukur dengan price book value lebih besar pengaruhnya dari pengaruh total struktur modal yang diukur dengan long term debt total assets terhadap nilai perusahaan yang diukur dengan price book value. Sehingga untuk meningkatkan nilai perusahaan lebih efektif melalui peningkatan debt to equity ratio.

\section{KETERBATASAN PENELITIAN}

Penelitian ini memiliki keterbatasan

1. Penelitian ini menggunakan sampel yang kurang respresentatif karena hanya mencakup perusahaan food \& beverage. Penelitian selanjutnya diharapkan sampel perusahaan jasa baik keuangan maupun non keuangan. Pengungkapan CSR lebih mendalam dan dijadikan variabel independen.

2. Nilai perusahaan hanya diukur dengan price book value. Penelitian selanjutnya diharapkan menambah ukuran untuk nilai perusahaan misalnya price book value dan price earning ratio. Sedang untuk struktur modal dapat ditambahkan ukuran misalnya total debt to total assets ratio.

\section{SARAN}

1. Bagi Perusahaan

Hasil penelitian ini diharapkan dapat menjadi pertimbangan bagi para manajer dalam menetapkan kebijakan terkait dengan CSR. Perlu dipertimbangkan tidak didukungnya hipotesis penelitian, kemungkinan disebabkan antara lain; pengukuran nilai perusahaan yang tidak tepat, pengungkapan CSR yang kurang mendalam, diuji sebagai variabel independen atau variabel moderating.

2. Bagi Investor

Hasil penelitian ini diharapkan dapat memberikan masukan bagi investor dalam melakukan investasi saham dengan melihat kondisi perusahaan melalui stuktur modal yang diukur dengan debt to equit ratio (seberapa besar hutang yang digunakan untuk membiayai perusahaan) dan nilai perusahaan (price book value).

3. Bagi peneliti selanjutnya

Sebaiknya pada penelitian- penelitian selanjutnya perlu lebih menggali tentang struktur modal, corporate social responsibility, dan nilai perusahaan. Agar penelitian selanjutnya lebih dalam dan detail, struktur modal ditambah dengan ukuran total debt to total asets ratio.Corporate social responsibility, bisa dijadikan variabel moderasi. Demikian juga untuk nilai perusahaan tidak hanya diukur dengan Price Book Value (PBV), tapi diukur dengan Tobin's Q dan Price earning Ratio (PER).

\section{DAFTAR PUSTAKA}

Anggraini,FR.ReniRetno.(2006)"PengungkapanInformasiSosialdanFaktor-Faktor

Mempengaruhi Pengungkapan Informasi Sosial dalam Laporan Keuangan Tahunan (Studi Empiris pada Perusahaan-Perusahaan yang terdaftar Bursa Efek Jakarta)."Simposium Nasional Akuntansi IXPadang23-26 Agustus2006

Asnawi, Said Kelana,.dan Wijaya, Chandra.,2006.,Metodologi PenelitianKeuangan ( Prosedur, Ide, dan Kontrol).,Graha Ilmu., Yogyakarta.

Brealey, R,A., dan S.C. Myers. 2003. Principle of Corporate Finance. Seventh Edition. New York : McGraw-Hill

Brigham,E.,F.,dan Gapenski, 1997. Financial Management: Theory and Practice,,Eighth Edition, Orlando, Florida: The Dryden Press.

Brigham, Eugene F., and Michael C. Ehrhardt, 2005, Financial Management: Theory and Practice, Eleventh Edition, South- Western, Australia, Thomson Learning. 
Brigham, Eugene, dan Houston Joel F. 2001. Manajemen Keuangan, Edisi Bahasa Indonesia, Jakarta,

Dahli,L.danSiregar,V.S.(2008)"PengaruhCorporateSocialResponsibilityterhadap Kinerja Perusahaan(StudiEmpirispadaPerusahaanyangTercatatdiBursaEfek Indonesia pada Tahun 2005 dan 2006)”. Simposium Nasional Akuntansi XI. Pontianak.

Darminto. (2010) "Pengaruh Faktor Eksternal dan Berbagai Keputusan Keuangan terhadap Nilai Perusahaan". Jurnal Aplikasi Manajemen. Vol: 8. No. 1. hal.138-150.

ErlanChairiri, Anis dan Imam Ghozali. 2007. TeoriAkuntansi. Fakultas Ekonomi: Universitas DiponegoroSemarang

Freeman,R.E.danMcVea， J.(2002)“AStakeholderApproachtoStrategicManagement.”InHitt, $\quad$ M., Freeman, R.E.

Fodio,MusaInuwa,AbdullahiMusabuAbdissAmaddanVictorChieduOba.2013.CorporateSocialResponsibilityandFirmValueinQu otedNigerian FinancialServices. InternationalJournalofFinanceandAccounting,2(7), pp: 331340.

Gunawan,B.danUtami,S.S.(2008)"PerananCorporateSocialResponsibilitydalamNilaiPerusahaan". Jurnal Akuntansi dan Keuangan. Vol: 7. No. 2, hal 174-185.

Ghozali, Imam, 2006, Analisis Multivariate dengan Program SPSS. Semarang, Badan Penerbit Universitas Diponegoro..

Gitman, Lawrence J., 1994, Principles of Managerial Finance, Seventh edition,New York: Harper Collins College Publishers.

Gherghina,StefanChristian,GeorgetaVintilaandDianaDobrescu.2015.An Empirical Research on the Relationship Between Corporate Social Responsibility Ratings and U.S. Listed Companies Value. Journal of Economics Studies and Research, 10(1), pp: 1-11.

Groth, J.C., dan R.C. Anderson.1997. "Capital Structure: Perspective for Managers", Management Decission,35/7: 552-561..

Gunawan,B.danUtami,S.S.(2008)"PerananCorporateSocialResponsibilitydalamNilaiPerusahaan". Jurnal Akuntansi dan Keuangan. Vol: 7. No. 2, hal 174-185.

Harjoto,MaretnoA.andHojeJo.2011.CorporateGovernanceandFirmValue:

TheImpactofCorporateSocialResponsibility.JournalofBusinessEthic,

5(1), pp: $258-270$

Indrawan, D.C. 2011. Pengaruh Corporate Social Responsibility TerhadapKinerjaPerusahaan.JurnalUniversitas Diponegoro Semarang,1(1), h:1-30

Irham Fahmi, 2011, Analisis Laporan Keuangan, Alfabeta, Bandung.

Iskandar, 2008, Metodologi Penelitian dan Sosial ( Kuantitatif dan Kualitatif ), Gaung Persada Press, Jakarta..

Joel G. Siegel dan Jae K. Shim, 1999, Kamus Istilah Akuntansi, Elex Media Komputindo, Jakarta (terjemahan).

Jones, Charles P, 1992, Investment : Analysis and Management, Fifth Edition, John Wiley and Sons Inc, New York.

Kurniasari,WiduridanYusniWarastuti.2015.TheRelationshipBetweenCSR andProfitabilityToFirmValueinSriKehatiIndex.InternationalJournal of EconomicBehaviour, 5(1), pp: 31-41.

Kusumajaya, Dewa Kadek Oka. 2011. Pengaruh Struktur Modal Dan Pertumbuhan Perusahaan Terhadap Profitabilitas Dan Nilai Perusahaan Pada Perusahaan Manufaktur Di Bursa Efek Indonesia, Tesis Program PascasarjanaUniversitas Udayana,Denpasar

Kusumawardhani,I.danNugroho,

J.S.(2010) "PengaruhCorporateSocialResponsibility, Size,danProfitabilitasterhadapEarningsResponseCoefficient".KajianAkuntansi. Vol: 5. No. 1, hal. 22-32.

Klapper, Leora. F. \& I. Love. ( 2002 ). "Corporate Governance, Investor Protection and Performance in Emerging Market". World Bank WorkingPaper.April.http:// ssrn. Com.

Masdar Mas'ud. 2008. Analisis Faktor-Faktor yang Mempengaruhi Struktur Modal dan Hubungannya 
Terhadap Nilai Perusahaan. Jurnal Manajemen dan Bisni. Volume 7.

Meggison, William L., 1997., Corporate Finance Theory, Massachusetts: Addison-Wesley.

Modigliani, Franco, and Miller, Merton H., 1958, The Cost of Capital Corporate Finance, and the Theory of Invesment, the American Economic Review, 48/3, 261- 297.

Modigliani, Franco, and Miller, Merton H., 1963, The Cost of Capital Corporate Income Taxes, and the Cost of Capital, the American Economic Review, 53/3, 433- 443.

Mulyadi,MartinSuryadanYunitaAnwar.2012.ImpactOfCSRTowardFirmValueandProfitability.TheBusi nessReviewCambridge,19(2),pp:316-322.

Myers, Stewart C.,1984.,the Capital Structure Puzzle, the Journal of Finance, 39/3, 575 - 592.

Nguyen,BichThi,HaiThiThanhTran,OanhHuangLe,PhuocThiNguyen,

ThienHiepTrinhandVietLe.2015.AssociationbetweenCorporatSocial Responsibility

Disclosures and Firm Value - Empirical Evidence from Vietnam. International Journal of Accounting and Financial Reporting,5(1), pp: 212-228.

Ogden, Joseph P.,Frank C. Jen, Philip F. O'Connor, 2003, Advance CorporateFinance, Policies, and Strategies, Upper Saddle River, New Jersey: Prentice Hall.

Octavia, Helen dan Hermi. (2014) "Pengaruh Tanggung Jawab Sosial Perusahaan Terhadap Kinerja Perusahaan (Studi Empiris Pada Perusahaan Manufaktur yang TercatatdiBursaEfekIndonesiaPadaTahun2010Dan2011)".e-JournalAkuntansi Trisakti, Volume. 1 Nomor. 1 Februari 2014

Pandey,I.M. 2002. Capital Structure and The Firm Charact erstics: EvidenceFrom An Emerging Market, TIMA Working Paper.

Rakhiemah, A. N. dan Agustia, D. (2009) "Pengaruh Kinerja Lingkungan terhadap CorporateSocialResponsibility(CSR)DisclosuredanKinerjaFinansialPerusahaan Manufaktur yang Terdaftar di Bursa Efek Indonesia". Simposium Nasional Akuntansi XII. Palembang.

Riduwan.,dan Kuncoro,Engkos Achmad.,2011.,Cara Menggunakan dan MemakaiPath Analysis ( Analisis Jalur ).,Alfabeta.,Bandung.

Ross, Stephen A, 1977, the Determination of Financial Structure: the Incentive-Signaling Approach, the Bell journal of Economics, 8/1, $23-40$.

Seitz, Neil, 1984, Financial Analysis: A Programmed Approach, Third Edition, Englewood Clieffs, New Jersey: A Reston Book Prentice- Hall, Inc.

Setiaji, Bambang. 2004. Panduan Riset dengan PendekatanKuantitatif., Program Pascasarjana, Universitas Muhammadiyah, Surakarta.

Servaes, Henri. AndTamayo Ane.2013.TheImpact of Corporate Social Responsibility onFirmValue: TheRolof CustomerAwarness. ManagementScience,59(5), pp: 10451061.

Siaw Peng Wan, 1999, Corporate Finance: Capital Structure Decision, workingPaper, Univercity of Illinois at Urbana-Champaign, $1-28$..

Silvia, Agustina. 2013. Pengaruh Profitabilitas dan Pengungkapan Corporate SocialResponsibilityTerhadapNilaiPerusahaan(StudiEmpirisPerusahaan

ManufakturyangTerdaftar di BEI).Jurnal Akuntansi, 1(1), h: 1-23.

Smith Jr., Clifford W., and Ross L. Watts, 1992, The Invesment Opportunity Set and Corporate financing, Dividend an Compensation Policies, Journal of Financial Economics; 32, pp. 263292.

Sugeng, Bambang, 2009, Pengaruh Struktur Kepemilikan dan Struktur Modal Terhadap Kebqakan Inisasi Dividen di Indonesia, Jurnal Ekonomi Bisnis, Th. 14 No. 1, Maret.

Suharto,Edi.(2007)PekerjaanSosialdiDuniaIndustri:MemperkuatTanggungjawabSosialPerusahaan (CorporateSocialResponsibility),Bandung: RefikaAditama

Sujoko \& Ugy Seobiantoro. (2007). Pengaruh Struktur Kepemilikan Saham, Leverage, Faktor Intern dan Faktor Ekstern Terhadap Nilai Perusahaan (Studi Empirik pada Perusahaan Manufaktur dan Non Manufaktur di Bursa Efek Jakarta). Jurnal Manajemen dan Kewirausahaan Vol. 9 No. 1, Hal: 41-48.

Tija,Olivia dan Lulu Setiawati.2012.Effectof CSR Disclosureto Firm Value : Study 
ForBankingIndustryInIndonesia.WorldJournalofSocialSciences,2(6), pp:169-178.

Walsh, Ciaran, 2004, Key Management Ratio; Rasio-rasio Manajemen Penting Penggerak dan Pengendali Bisnis, Edisi 3, Jakarta ,Erlangga.

Widjaja. Indra, 2009, Pengaruh Firm Size dan Capital structure terhadap Prospek Saham Perusahaan, Jurnal Organisasi dan Manajemen,Tahun II, No.1, Januari 2009: 21-30.

Wiagustini,N.L.P.2013.ManajemenKeuangan.Denpasar:UdayanaUniversity Press. 